\title{
Ledelse af digital transformation: Erfaringer fra et kommunalt digitaliseringsinitiativ
}

\author{
Af Jeppe Agger Nielsen, Kasper Elmholdt og Mette Strange Noesgaard *)
}

\begin{abstract}
Resumé
Mange offentlige digitaliseringsinitiativer slår fejl eller lever ikke op til forhåbningerne. Ofte bliver mangelfuld ledelse fremhævet som en årsag hertil. I lyset heraf, rapporterer denne artikel fra et kommunalt digitalt transformationsinitiativ, hvor forandringsledelsesindsatsen var massiv. Studiet er designet som et kvalitativt casestudie af indførelsen af en ny digital platform til sundhedspersonalet i Aldre- og Handicapforvaltningen i Aalborg Kommune som indebar omfattede organisatoriske forandringer. Vi fremhæver tre forandringsledelsespraksisser, som var væsentlige for ledelsen af den digitale transformation: (1) tilpasningsledelse, (2) tilslutningsledelse og (3) forventningsledelse. Artiklen udfolder de tre ledelsespraksisser og illustrerer hvordan ledelse af digital transformation udspiller sig som en pragmatisk kombinering af praksisserne. Vi peger også på, at forandringsledelse i digital transformation får en særlig dimension, hvor det løbende handler om at forme aktørernes teknologiforståelser.
\end{abstract}

\section{Emneord}

Digitalisering, Digital transformation, Forandringsledelse, Digital platform, Casestudie 
*) Jeppe Agger Nielsen er professor, Kasper Elmholdt er adjunkt, og Mette Strange Noesgaard er adjunkt - alle er ansatte ved Institut for Politik \& Samfund på Aalborg Universitet.

\section{A. Indledning}

\section{Baggrund}

Digitalisering er et gennemgående tema i modernisering af den offentlige sektor (Danziger et al., 1982; Ejersbo \& Greve, 2016), fx karakteriseret som en ny digital era governance (Dunleavy et al., 2006). I de senere år er digital transformation, et begreb udviklet i private sektor kontekst (Vial, 2019), begyndt at vinde indpas i den offentlige sektor (Jonathan, 2020), men "the literature so far has not provided many details on how to orchestrate this transformational change" (Mengel, Edelmann \& Haug, 2019 p. 3).

Mens det debatteres i litteraturen, hvad digital transformation er (og ikke er) (Wessel et al., 2020) følger vi Hanelt et al's. (2020) definition af digital transformation som "organizational change that is triggered and shaped by the widespread diffusion of digital technologies" (p. 2). Et sådant udgangspunkt giver mulighed for at belyse digital transformation, og ledelse heraf, ved at knytte an til en bredere litteratur om organisationsforandring. Fra dette perspektiv er fokus ikke på softwareopgraderinger eller IT-forbedringsprojekter, men på væsentlige organisatoriske forandringer muliggjort af digitale teknologier såsom internet of things, kunstig intelligens, digitale platforme og mobil teknologi (Vial, 2019).

Eftersom digital transformation handler om at benytte digital teknologi til at fremme større organisatoriske forandringer, er ledelse af digital transformation en central, men vanskelig opgave. Mange studier rapporterer, at digital-drevne forandringsinitiativer i den offentlige sektor ofte slår fejl (Goldfinch, 2007; Dwivedi et al. 2015). Eksempelvis er det blevet fremhævet, at 20-30 procent af projekterne mislykkes totalt og 30-60 procent mislykkes delvist med "time and cost overruns or other problems" (Gauld, 2006, s. 103; Goldfinch, 2007). Selvom disse fejlestimater kan problematiseres, indikerer de, at digitaliseringsprojekter mange gange ikke lever op til forhåbningerne. Selvom Danmark i international målestok rangerer blandt de førende lande inden for offentlig digitalisering (EU, 2018) er fortællingen om offentlig digitalisering også, at større initiativer ofte ikke lever op til, fx politiske ambitioner, om at skabe en bedre, billigere og mere responsiv offentlig sektor (Dwivedi et al. 2015; Røhl \& Nielsen, 2019).

Ofte bliver dårlig eller manglende ledelse fremhævet som årsag til fejlslagen digitalisering (Nielsen \& Pedersen, 2014; Anthopoulos, et al., 2016; Askedal, Flak \& Aanestad, 2019). Det Digitale Råd (2012) i Danmark har ligefrem påpeget et behov for et paradigmeskifte i den offentlige ledelseskultur, hvor staten, regioner og kommuner skal blive bedre til at lede den digitale 
transformation. I lyset af denne opfordring, zoomer vi i denne artikel ind på, hvad der kan læres fra et kommunalt digitalt transformationsinitiativ, hvor ledelsesindsatsen var massiv.

\section{Artiklens formål}

Artiklen bygger på et kvalitativt casestudie i Ældre- og Handicapforvaltningen i Aalborg Kommune, hvor vi studerede indførelsen af en ny digital platform (CURA) med dertilhørende mobile enheder som tablets og smartphones til ca. 5.000 medarbejdere i ældreplejen over en toårig periode fra forberedelse til ibrugtagning. Denne forandring blev beskrevet af vores informanter som et "paradigmeskifte", "en kulturel forandring" og "det største implementeringsprojekt som forvaltningen har stået overfor", hvilket afspejler projektets transformative potentiale. Med afsæt i denne case, koncentrerer vi os om hvordan organisationer kan orkestrere digital transformation med afsæt i følgende problemstilling: Hvilke forandringsledelsespraksisser karakteriserer implementering af digital transformation i den offentlige sektor?

Vores studie illustrerer, hvordan ledere i Ældre- og Handicapforvaltningen benyttede forskellige forandringsledelsestilgange. Ledelsesindsatsen var både dikterende og inddragende, hvor ledelsen satte retningen oppefra og samtidig engagerede medarbejdere i forberedelsen og implementeringen af den nye digitale platform. Vi identificerede tre ledelsespraksisser som var særligt karakteristiske (1) tilpasningsledelse, (2) tilknytningsledelse og (3) forventningsledelse. Vi udfolder de tre praksisser og viser, hvordan ledelse af digital transformation udspilles, ikke via et skifte mellem praksisserne over tid (sekvensering), men gennem en pragmatisk kombinering. Vi viser samtidig, hvordan aktive forsøg på at forme aktørernes teknologiforståelser og forventninger til fremtiden bliver en væsentlig forandringsledelsesopgave i digital transformation.

\section{Oversigt over artiklen}

I det efterfølgende afsnit præsenteres artiklens teoretiske bagtæppe for dernæst at redegøre for case og dataindsamlingsmetoder. Herefter følger analysen og en diskussion af analyseresultaterne for slutteligt at sammenfatte artiklens hovedbudskaber og forskningsmæssige bidrag.

\section{B. Teoretisk bagtæppe: Ledelse af digital transformation i organisationer}

Digital transformation knytter sig til organisatorisk forandring (Hanelt et al., 2020) og indebærer at medarbejdere og/eller ledere skal ændre arbejdsrutiner mv., hvorfor en primær opgave er at lede mennesker igennem transformationen. Forandringsledelse er netop optaget af den menneskelige dimension og udgør derfor et væsentligt aspekt af digital transformation (Ashust, Doherty \& Peppard, 2008; Hansen \& Nørup, 2017). Forandringslitteraturen er omfattende og mange facetteret, men kan groft opdeles i en funktionalistisk og konstruktivistisk tradition. 
Inden for den funktionalistiske tradition findes en række populære ofte normative udlægninger af, hvordan forandringsprocesser bør ledes (fx Kotter, 1995). Her er fokus på, hvordan topledelsen kan kommunikere et relativt entydigt billede af forandringen og styre via vekslen mellem dirigerende og involverende tilgange (Beer \& Nohria, 2000) med et fokus på at skabe de rette strukturer, planer og incitamenter (Beer \& Nohria, 2000; Kotter, 1995; Kanter et al., 1992) og motivere forandring gennem en "brændende platform" hos medarbejderne (Kotter, 1995). Fra dette perspektiv kan dikterende og involverende forandringsledelse varieres under hensyntagen til forandringens størrelse og kompleksitet (Elmholdt, Keller \& Tanggard, 2019; Ford et al. 2008). Involvering og diktering kan eksempelvis anvendes i forlængelse af hinanden (Huy, 2001), hvilket er synligt fx hos Fernandez og Rainey (2006), der anbefaler offentlige ledere indledende at identificere og kommunikere et tydeligt behov for forandring, udarbejde en forandringsplan og overvinde modstand. Involvering og diktering kan også anvendes i forskellige dele af organisationen (Jacobsen, 2019) eller flere tilgange kan bringes i spil samtidig (Hansen \& Nørup, 2017; Huy, 2001). Denne litteratur har dog flere begrænsninger, fx et relativt centralistisk fokus på ledelse, og en statisk forståelse af forandring (fx Kotter, 1995).

Som et alternativ til denne litteratur, har en række studier været inspireret af konstruktivistiske perspektiver på forandring (Weick \& Quinn, 1999; Crevani, 2018). Her fremhæves det, at forandringsledelse ikke alene handler om topledelse, men involverer en række aktører, der alle kan være med til at skabe retning gennem diskursive og materielle virkemidler (Rouleau, 2005; Elmholdt, Clausen \& Madsen, 2017). Denne litteratur betoner, hvordan mellemledere, konsulenter og projektledere kan spille en afgørende rolle $\mathrm{i}$ at håndtere forandringer i praksis. Fokus har eksempelvis været på, hvordan mellemledere har en afgørende rolle som "sælgere” af forandringer i hverdagen (Rouleau, 2005). Fra dette perspektiv er ledelse ikke synonym med topledelsen eller lederen af it-afdelingen, men er en aktivitet, der er distribueret og deles med fx mellemledere, frontlinjeledere og medarbejdere. Ledelse kan her forstås som "produktion af retning" i en løbende proces, der involverer mange aktører (Crevani, 2018). Mens denne sidstnævnte litteratur bidrager med væsentlige nuancer, er fokus stadig primært på forandring som et generisk koncept, der såvel kan vedrøre strategi, kultur, struktur og teknologi, men det særlige ved at lede digitale transformationsprocesser er underbetonet.

\section{Kræver det noget særligt at lede digital transformation?}

Ledelse af digital transformation kendetegnes ved at være centreret om digitale teknologier-eller digitale artefakter. Flere har påpeget væsentligheden i netop at forholde sig til det særlige ved dette (Faulkner \& Runde, 2019; Orlikowski \& Iacono, 2001). Digitale teknologier er kendetegnet ved at 
have et materielt-funktionelt design, som muliggør (og vanskeliggør) bestemte handlinger (Orlikowski, 2000), men samtidig er digitale teknologier ikke neutrale eller entydige. Digitale teknologiers betydning og brugspotentiale formes i det fællesskab, hvori de bringes i anvendelse (Faulkner \& Runde, 2019). Denne betydningsmæssige plasticitet danner grundlag for digitale teknologiers "fortolkningsmæssige fleksibilitet" (Pinch \& Bijker, 1984; Sahay \& Robey, 1996). Pointen er, at digitale teknologier ikke tillader en hvilken som helst fortolkning, de er medieret af deres design, men påvirkes samtidig af bl.a. kulturen i organisationen og en dynamisk omverden. Denne observation er videreudviklet af fx Orlikowski (2000) som illustrerer, hvordan samme digitale teknologi kan opleves væsensforskelligt på tværs af aktørgrupper såsom systemudviklere, ledere og medarbejdere, men også internt i grupperne er der forskelle, og aktørernes oplevelser kan ændres over tid i takt med at teknologien anvendes (Nielsen Mathiassen \& Newell, 2014). Disse karakteristika får betydning for ledelse af digital transformation i organisationer, og lægger sig særligt i forlængelse af den konstruktivistiske forståelse af forandringsledelse, hvor den løbende formning af aktørernes forståelser af digital teknologi og forventninger bliver væsentlige forandringsledelsesopgaver.

\section{Metode}

\section{Konteksten}

Ældrepleje udgør et kerneområde i velfærdsstaten, hvor det efter en decentral model er kommunerne, som har ansvaret for levering af serviceydelserne (Nielsen \& Andersen, 2006). Eldreplejen har i de senere årtier gennemgået en omfattende digitaliseringsproces fx via implementering af elektroniske omsorgsjournaler og ibrugtagningen af mobil teknologi blandt pleje- og sundhedspersonalet (Nielsen, et al., 2014). Den elektroniske omsorgsjournal udgør en digital platform, hvor grundtanken er, at oplysninger om borgeren (stamoplysninger, funktionsvurdering, plejeplaner mv.) skal være samlet ét sted og at data er tilgængelige for relevante faggrupper på tværs af tid og sted, som kan tilgås via mobile terminaler såsom bærbare computere, tablets og smartphones (Mogensen, 2019).

Aldre- og Handicapforvaltningen i Aalborg Kommune, som udgør denne artikels case, har et årligt budget på 3.0 mia. kr. Ældreplejen repræsenterer forvaltningens største afdeling og varetager hjemmepleje som tilbyder personlig pleje og omsorg i borgernes hjem, hjemmesygepleje og plejehjem. Afdelingen har omkring 5.000 ansatte, primært frontlinjemedarbejdere som sosuassistenter, hjemmesygeplejersker og psykoterapeuter, som varetager afdelingens tilbud med særligt fokus på pleje, sundhed og rehabilitering af borgeren. 


\section{Empiri}

Metodisk er studiet designet som et kvalitativt single casestudie i Ældre- og Handicapforvaltningen med inddragelse af flere datakilder: interviews, dokumenter og observationer. Empiriindsamlingen påbegyndtes i maj 2018 (12 måneder før ibrugtagning af CURA platformen) og blev afsluttet i marts 2020 (10 måneder efter ibrugtagning). Deltagere fra kommunen blev alle informeret om regelsættet i GDPR-lovgivningen forud for interviews og data er opbevaret og behandlet i overensstemmelse med GDPR.

Vi interviewede forvaltningsledelsen (direktøren, fagchefer, IT chefer), CURA projektorganisationen (projektledere, projektmedarbejdere), mellemledere (områdeledere, centerledere, plejehjemsledere mv.) og medarbejdere i frontlinjen (sosu-assistenter, hjemmesygeplejersker mv.) for at skabe en indgående forståelse for transformationsprocessen fra forskellige organisatoriske positioner. Vi var særligt interesserede i, hvordan den digitale transformation blev grebet an ledelsesmæssigt, anvendte forandringsledelsestilgange ( $\mathrm{f} x$ topledelsens involvering og graden af medarbejderinvolvering), hvordan de forskelige aktører oplevede ledelsen af transformationsprocessen og selve "resultatet" af indførelsen af CURA. Som opsummeret i Tabel 2, gennemførte vi i alt 53 interviews. Hovedparten af interviewene blev gennemført face-to-face hos respondenterne. De resterende via telefon eller MS Teams.

Ud over interviewene består datamaterialet af en række dokumenter, heriblandt referater fra ledergruppemøder og styregruppemøder samt kommunikation om CURA-projektet på kommunens hjemmeside. Dokumentanalyse bidrog med at skabe en forståelse for den formelle ledelsesstil og forandringsprocessens forløb og prioriteringer samt kommunikation heraf. Endelig deltog vi som observatører på en række leder- og medarbejdermøder om CURA, hvor vi tog detaljerede feltnoter. 


\begin{tabular}{|l|l|}
\hline \multicolumn{2}{|l|}{ Interviews } \\
\hline 1. runde: Før CURA ibrugtagning & $\begin{array}{l}\text { Mellemledere: } 11 \\
\text { Medarbejdere: } 12\end{array}$ \\
\cline { 2 - 3 } (maj 2018 - april 2019) & $\begin{array}{l}\text { Forvaltningsledelse: } 8 \\
\text { CURA projektorganisation: } 4\end{array}$ \\
\hline $\begin{array}{l}\text { 2. runde: Efter CURA-ibrugtagning } \\
\text { (september 2019 - marts 2020) }\end{array}$ & $\begin{array}{l}\text { Mellemledere: } 7 \\
\text { Medarbejdere: } 11\end{array}$ \\
\hline $\begin{array}{l}\text { Projektbeskrivelser, referater fra møder, } \\
\text { herunder styregruppemøder mv. }\end{array}$ & +300 siders tekst \\
$\begin{array}{l}\text { Kommunikation om CURA projektet, fx via } \\
\text { Aalborg Kommunes hjemmeside }\end{array}$ & +70 minutters video \\
\hline \multicolumn{2}{|l|}{ Observation } \\
\hline \begin{tabular}{l} 
Mødedeltagelse \\
\hline
\end{tabular}
\end{tabular}

Tabel 1: Oversigt over datamateriale indsamlet i Aldre- og Handicapforvaltningen.

\section{Dataanalyse}

Alle interviews blev transskriberet med assistance fra en gruppe studentermedhjælpere. Vi benyttede softwareprogrammet NVivo 12 til at understøtte analysearbejdet med udgangspunkt i tematisk kodning (Braun \& Clarke, 2006). I 1. runde kodning arbejdede vi med en række generelle forandringsledelsestematikker såsom formål med indførelse af CURA, centrale aktører involveret i at drive den digitale transformation, medarbejderinvolvering og oplevede virkninger af forandringen. Det stod hurtigt klart, at topledelsens fokus på CURA var stort. CURA blev italesat af vores respondenter som "et prestigeprojekt der skal lykkes", "jeg oplevede langt større opmærksomhed fra topledelsen end ved indførelse af andre IT systemer", og "forvaltningsledelsen er gået foran”. Disse observationer og vores stigende grad af kendskab til empirien (Braun \& Clarke, 2006) dannede grundlaget for en mere fokuseret kodning, som udgør fundamentet for artiklens analyse.

I 2. runde kodning zoomede vi ind på konkrete forandringsledelsespraksisser. I en iterativ proces, knyttede vi de empiriske observationer sammen med såvel den funktionalistiske forandringsledelseslitteraturs fokus på topledelsens rolle, samt den konstruktivistiske litteraturs fokus på forandringsledelse som løbende og distribueret arbejde. Videre var vi særligt interesserede i at forstå, hvilken rolle den digitale teknologis materialitet og fortolkningsmæssige fleksibilitet spillede. Herigennem udkrystalliserede sig en række forandringsledelsespraksisser, som vi har inddelt i tre kategorier: Tilpasningsledelse som markerer iværksættelse organisatoriske og tekniske tilpasninger, tilslutningsledelse som markerer mobilisering af nøgleaktører og skabe opbakning 
gennem løbende involvering og forventningsledelse som markerer at forme aktørernes teknologiforståelse og fremtidsforventninger.

\section{Introduktion til case}

I 2017 besluttede Ældre- og Handicapforvaltningen at investere i en ny digital platform (CURA) med tablets og smartphones til alle frontlinjemedarbejdere. Skiftet til CURA blev fremskønnet af et nationalt krav om implementering af Fælles Sprog 3 (FSIII) som standard for social- og sundhedsfaglig dokumentation på ældreområdet (KL, 2018). Den eksisterede platform —som havde været benyttet i organisationen i 25 år kunne ikke håndtere denne opgave, men med CURA fik forvaltningen en digital platform som kunne håndtere FSIII's dokumentationskrav. I de officielle formål blev det fremhævet, at CURA skulle bidrage til (a) smartere og hurtigere løsning af kerneopgaven, (b) mindre tid på registrering og dokumentation, med en forventet årlig besparelse på 5 mio., (c) mere ensartet dokumentation og (d) styrket samarbejde på tværs i forvaltningen.

Skiftet til CURA på ældreområdet omfattede et enormt arbejde, herunder udarbejdelse af kravspecifikationer og implementeringsplaner, håndtering af leverandør-relationer, uddannelse af 5.000 medarbejdere og iværksættelse af et superbruger-korps. Som illustration af projektets kompleksitet, blev CURA platformen integreret med 28 andre IT-systemer (internt og eksternt) som eksempelvis Fælles Medicinkort (FMK) og Sundhedsvæsnets Klassifikationssystem. Organiseringen af CURA projektet havde på øverste niveau en Styregruppe, som bl.a. bestod af forvaltningsdirektøren, chefen for ældreområdet, IT chefen, og den politiske rådmand på området. Under Styregruppen blev der etableret et Projektkontor, anført af den daglige projektleder, som havde ansvaret for at sikre fremdrift i projektet. Herudover blev der etableret implementeringsgrupper og grupper med ansvar for funktionelle opgaver, så som undervisning.

Implementeringen blev organiseret som "big bang" hvor forvaltningen skiftede platform på én gang. "Go-live" datoen var planlagt i oktober 2018, men grundet tekniske og organisatoriske udfordringer valgte forvaltningsledelsen i sensommeren 2018 at udskyde go-live tidspunktet til d. 15. maj 2019, hvor CURA officielt blev taget i brug.

\section{E. Analyse}

Det som er scerligt ved digital transformationsinitiativer, som fx CURA projektet, er, at uanset hvor god din implementeringsplan er, så opstår der altid flere kritiske udfordringer. De gode viljer fra leverandør, projektledelse, styregruppe og medarbejdere er aldrig nok. Man skal som ledelse vare $i$ stand til at agere hurtigt og kunne troeffe beslutninger på et ikke altid fuldt oplyst grundlag (direktør). 
Som det fremgår af citatet, er ledelse af digital transformation en krævende opgave med usikkerheder og uforudsete hændelser. I den følgende analyse, illustrerer vi de tre identificerede forandringsledelsespraksisser.

\section{Tilpasningsledelse}

Tilpasningsledelse markerer, at der løbende foretages organisatoriske og tekniske tilpasninger for at geare organisationen til digital transformation.

I den tidlige fase af projektet, blev det en central ledelsesopgave at reorganisere CURA projektorganisationen. Denne opgave tog fart, efter kontrakten med Systematic var på plads, hvor det hurtigt stod klart, at forvaltningsledelsen havde undervurderet omfanget af projektet. Mens der i starten af projektforløbet (2017) var én fuldtidsansat med ansvaret for CURA projektet, var der tre år senere 15-20 fuldtidsansatte i CURA projektkontoret med ansvarsområder som konfiguration, test, uddannelse, drift og support. Denne ledelsesbeslutning om at opgradere projektkontoret kan umiddelbart betragtes naturlig, men det var langt fra en udvikling, der gav sig selv. En projektleder fortalte:

Altså vi har jo været på en rejse, en udviklingsrejse, der siger spar to, tænker jeg. For da projektet startede, efter kontrakten med Systematic var underskrevet, jamen der sad jeg som den eneste fuldtidsansatte. $\mathrm{Nu}$ har vi jo etableret en stor projektorganisation.

Medio 2017 opstod der i forvaltningsledelsen en erkendelse af, at projektorganisationen måtte oprustes for at favne den digitale transformation. Derfor tog forvaltningen kontakt til et konsulenthus for at få sparring på deres egen udviklede projektorganisering. En chef forklarede:

Det var især efter vi fik konsulenthuset ind over og fik fokus på det organisatoriske mere end det teknologiske, at den interne økonomi svulmede op. Forstået på den måde, at dels har vi fået et større projektkontor og har måttet frikøbe medarbejdere. Også hele uddannelsesdelen har fået et langt større omfang, end vi havde drømt om.

Som det fremgår af citatet, anbefalede konsulenthuset en kraftig reorganisering af projektorganisationen, som krævede økonomiske ressourcer til ansættelse af flere medarbejdere i projektkontoret. Hertil kom udgifter til et superbruger-korps, hvor mere end 250 medarbejdere blev særligt uddannet og frikøbt fra driften for at indgå i projektorganisationen med henblik på at sikre opbakning og bedst mulig tilpasning af CURA til lokale arbejdspraksisser. 
Relateret til den organisatoriske tilpasning var teknisk tilpasning en central del af ledelsesopgaven. Selvom CURA allerede var taget i anvendelse i andre kommuner, skulle platformen tilpasses Aalborg Kommunes specifikke behov. Denne tilpasning skete blandt andre i samarbejde med systemleverandøren. En projektmedarbejder forklarede:

Vi arbejder hele tiden på at tilpasse systemet til de praktiske udfordringer, som vi møder. De udfordringer, vi eksempelvis får øje på i forhold til arbejdsgange, er vi i løbende dialog med Systamatic om at løse.

Desuden skete tilpasningen gennem en række workshops, hvor medarbejdere og superbrugere blev inddraget til at kvalificere platformens design, og hvor arbejdspraksisser blev kortlagt. På baggrund af disse workshops blev et tilpasset CURA udviklet og gjort klar til udrulning. Disse tilpasninger var dog ikke lige til, og i sensommeren 2018 besluttede forvaltningsledelsen at udskyde "go-live" tidspunktet for CURA med seks måneder fra oktober 2018 til maj 2019. Denne justering skete i erkendelse af, at (1) CURA projektet organisatorisk var langt større og mere omfattende end oprindeligt antaget, (2) at CURA systemet teknisk ikke var klart på daværende tidspunkt.

Medarbejdere og mellemledere udtrykte blandede oplevelser af udskydelsen. Nogle begyndte at så tvivl om kvaliteten af selve platformen, men de fleste så udskydelsen som en styrkelse af projektet. En mellemleder fortalte:

At man valgte at udskyde var fantastisk. Processen er blevet SÅ meget bedre. Nu har jeg ro i maven, for jeg ved der er styr på arbejdsprocesser, arbejdsgangsbeskrivelser og så videre.

Efter adskillige organisatoriske og tekniske tilpasninger blev platformen taget i brug i maj 2019. I den efterfølgende fase fortsatte den tekniske og organisatoriske tilpasning. Projektledelsen holdt løbende møder med superbrugere og andre ressourcepersoner for løbende at sikre tilpasning af platformen og imødekommelse af fejl, som opstod undervejs. En medarbejder på en genoptræningsklinik pointerede, at systemet havde flere begrænsninger "som ikke lige står til at aendre". Det viste sig dermed, at systemet i kølvandet på ibrugtagningen krævede tilpasninger, som strakte sig ud over hvad man havde forventet indledningsvist. Dette betød, at ledelsen løbende var i dialog om tilpasning af systemet, hvilket indebar, "voldsomt mange møder med systemleverandøren" som en projektleder udtrykte det. I det hele taget blev det betonet, at tilpasningsarbejdet og ledelse heraf er en langvarig proces. En IT chef formulerede det således primo 2020: 
Implementeringen er langt fra i hus, det kommer til at tage flere år, før CURA for alvor 'sidder der'.

\section{Tilslutningsledelse}

Denne forandringsledelsespraksis markerer, at nøgleaktører mobiliseres og der skabes opbakning gennem løbende involvering.

Forvaltningsledelsen var optaget af at sikre tilslutning til CURA gennem en inddragende proces. En IT-chef forklarede:

Inddragelse var gennemgående i hele den måde vi tænkte det på, både i udbudsprocessen og kravsspecifikationsarbejdet, men også i den måde vi kommunikerede over for medarbejdere, og også borgere i sidste ende. Så inddragelse er jo det, som har været en motor i hele det her arbejde.

Medarbejderne gav udtryk for, at inddragelse havde en positiv indvirkning på deres tilgang til projektet. En mellemleder udtalte:

Der er virkelig sat ind i starten for at gøre os parate, der var læringspakker og meget kommunikation om CURA.

En anden supplerede:

Der var gjort rigtig meget for at infomere medarbejdere, så de løbende var med og vi har følt os meget privilegeret ved at få vores stemme hørt.

Som citaterne illustrerer, var løbende information og lydhørhed fra forvaltningsledelsessiden vigtige elementer i medarbejdernes og mellemledernes forberedelse på den nye platform. Organisationens "stemme" blev hørt.

De mange superbrugerne spillede en vigtig rolle i at øge tilslutning på lokalt niveau. På de enkelte institutioner (plejehjem mv.) blev der fritstillet ressourcer, så udvalgte medarbejdere kunne påtage sig rollen som superbrugere. En mellemleder fortalte:

Vi havde nogle superbrugere, som blev uddannet til at kunne hjælpe, og vi fik løbende indspark om, hvad der kunne hjælpe os. Så på den måde synes jeg, vi har været rigtig, rigtig meget med. 
Samlet set, investerede kommunen massivt i superbrugere, uddannelse, læringspakker og elæringsforløb til forvaltningens medarbejdere. Selvom uddannelsesaktiviteterne havde et hovedsigte mod at uddanne medarbejdere i CURA platformen, var det vigtigt, at det var udvalgte medarbejdere, som uddannede andre medarbejdere, og derved også var med til at give teknologien og forandringen retning (jf. Rouleau, 2005). Det var således ikke eksterne undervisere, som forestod undervisningen, men de udvalgte undervisere, der senere agerede superbrugere, bidrog til at sikre en forståelse af fælles ståsted blandt medarbejderne.

Ved løbende at mobilisere strategiske medarbejdere fungerede tilslutningsledelse således som en gradvis udvidelse af deltagermassen i udrulningen. Afgørende for tilslutningsledelse var skabelsen af en oplevet indflydelse hos medarbejderne, som ofte fremhævede et stort engagement og ejerskab for projektet hos forvaltningsledelsen, hvilket det følgende citat fra en medarbejder illustrerer:

Det virker til ledelsen mener, at dette er en vigtig implementering, for de har sat ind på alle fronter og afsat rigtig meget tid og ressourcer.

Der tegnes mao. et billede af en forvaltningsledelse, der "gik foran", og som allokerede "de nødvendige ressourcer for at få CURA til at lykkes og få hele organisationen med", som en mellemleder formulerede det. Dog observerede vi også, at visse medarbejdere og mellemledere begyndte at stille spørgsmålstegn ved, om kommunen brugte for mange ressourcer på at få projektet til at blive en succes, herunder omfanget af medarbejderinddragelse og diverse online kurser. En medarbejder udtrykte sin tvivl på følgende vis:

Vi har virkelig brugt mange timer på at forberede os på den nye platform. Altså nogle af os havde måske ikke behøvet at gennemgå hele pakken. Men ledelsen tænkte nok, at alle skulle have samme 'tur'. Jeg synes bare, det var lidt spild af tid og penge.

Tilslutningen var generelt stor, men dog var ikke alle overbeviste om prioriteringerne, og forventningsledelse, som vi vil se i det næste afsnit, blev et centralt element $\mathrm{i}$ at håndtere disse frustrationer.

\section{Forventningsledelse}

Forventningsledelse handler om at forme aktørernes forståelse af og fremtidsforventninger til digital transformation. I casen observerede vi, at forvaltningsledelsen retorisk søgte at "frame" CURA i en bestemt retning, og hvordan de senere måtte "re-frame" og justere forventninger til teknologien og fremtiden, da transformationsprocessen udfoldede sig på uventede måder. 
Fra forvaltningsledelsens side blev CURA forud for ibrugtagningen italesæt i særdeles positive toner. Behovet for CURA blev retfærdiggjort gennem retorik som "forceldede IT systemer", "behov for at kunne arbejde bedre på tvaers af forvaltninger" og "behov for mere kvalitet i dokumentation". Det er værd at bemærke, at forvaltningsledelsen ikke italesatte CURA som et besparelsesprojekt-og at det heller ikke blev oplevet sådan af de mellemledere og medarbejdere, vi interviewede. En kalkuleret årlige besparelser på 5.0 mio. kr. blev-en anelse karikeret-beskrevet som "en dråbe i havet" og et beskedent beløb i en forvaltning med et årligt budget på 3.0 mia. kr. På den måde skabte forvaltningsledelsen en legitim begrundelse for den nye platform gennem en retorik, som appellerede til modernisering og ikke-økonomiske begrundelser.

I bestræbelserne på at forme aktørenes forventninger til den nye platform tog forvaltningsledelsen en række virkemidler i brug af både substantiel (fx uddannelse og superbrugere) og symbolsk karakter (fx konkurrencer og merchandise). CURA projektet fik i 2018 sin egen hjemmeside, som løbende bragte nyheder og hvor man kunne tilgå en række videoklip, hvor ledere og medarbejdere fortalte om forventninger, forhåbninger og brug af den nye platform (https://cura.aalborg.dk/omcura). På hjemmesiden findes $\mathrm{fx}$ videoer med forvaltningsdirektørens tale til organisationen umiddelbart før "go-live" datoen. Hvad angår de mere symbolske handlinger, blev der retorisk anvendt besnærende slogans som "CURA - en god kollega" og udbudt konCURAncer, hvor vinderne fik en CURA-kurv. Systematic bidrog med merchandise såsom "CURA-vand" (se Figur 1).
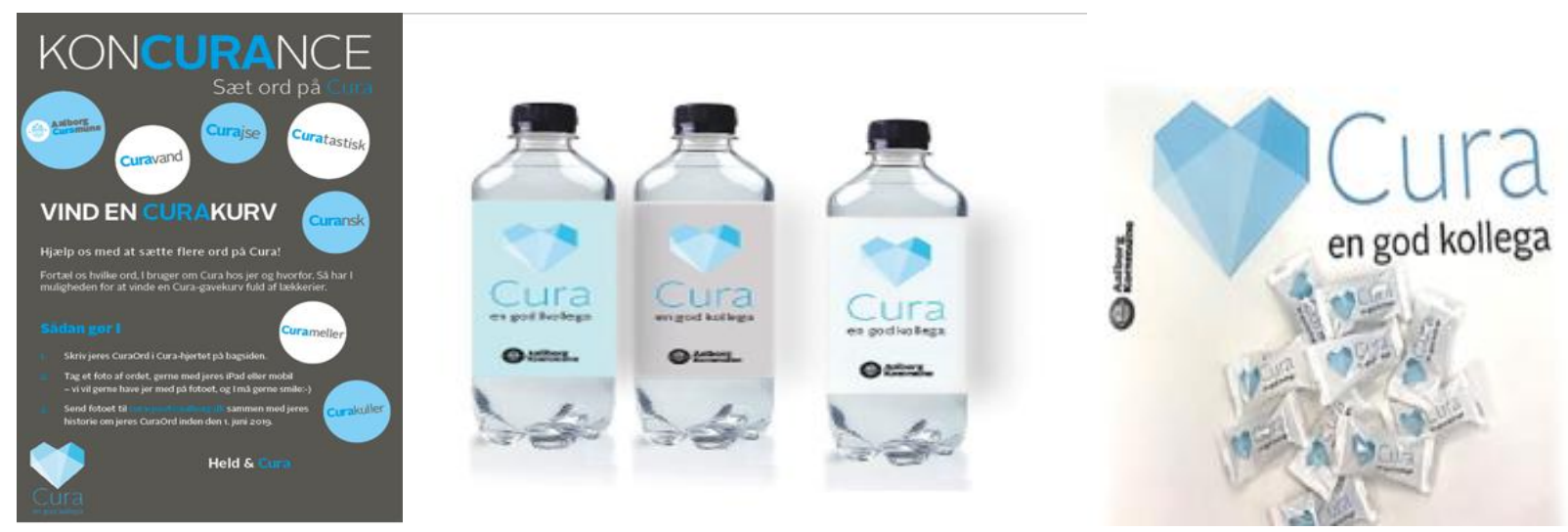

Figur 1: Eksempler på CURA merchandise mv.

Disse billeder på CURA var synlige mange steder i forvaltningen, hvor der hang plakater, der informerede om CURA og opfordrede medarbejdere til at engagere sig i udrulningen af den nye platform. Samlet bidrog forvaltningsledelsens arbejde med løbende forsøg på at forme medarbejdernes forståelser og forventninger til CURA, som en digital platform, der ikke skulle føre til øget dokumentation og være begrænsende, men snarere som en ny, spændende mulighed. Ikke 
alle medarbejdere accepterede ubetinget denne form for forventningsledelse. Eksempelvis observerede vi, at en gruppe medarbejdere i hjemmeplejen havde tegnet en dinosaurus og skrevet "Curasic Park" på en tavle, hvilket indikerede en modstand mod de positivt rettede symboler. Hertil kommer, at reaktioner fra navnlig mellemledere og medarbejdere 8-10 måneder efter CURA ibrugtagning tegner et billede af, at de høje forventninger (endnu) ikke er indfriet. Flere beskrev, hvordan forvaltningsledelsen havde tegnet et næsten perfekt billede af "super systemet CURA", som det i praksis havde vanskeligt ved at leve op til.

Forvaltningsledelsen var opmærksom på, at de opskruede forventningerne til CURA kunne skabe problemer, og at der var behov for at "re-frame" medarbejdernes forventninger. På flere møder blev det pointeret, at implementeringen ikke er overstået endnu. På et ledermøde otte måneder efter systemet var taget i brug, tydeliggjorde direktøren:

Før CURA er fuldstændig integreret i vores hverdag, vil der gå i hvert fald to år, og den tidshorisont må vores medarbejdere kende.

En IT-chef tilsluttede sig dette og understregede:

At arbejdet er langt fra ovre, og det må vores medarbejdere også vide - det er alt for tidligt at fælde dom over CURA. Vi skal fortsat implementere og massere organisationen.

Den forståelse bredte sig også blandt medarbejderne, som blandt andet sagde:

Lige nu er vi ved version 1.0, og vi skal jo op på version 3.0, før vi er rigtig oppe at køre, så der er noget vej endnu.

En form for forventningsledelse viste sig, hvor tid og tålmodighed blev en strategisk vigtig dimension i forhold til at håndtere mangler ved CURA.

Forventningsledelse viste sig således på en måde, hvorpå medarbejdernes forventninger til CURA løbende blev forsøgt formet i bestemte retninger. I starten bestod det i at signalere overfor medarbejderne, at den nye platform tilbød nye muligheder for at samarbejde på tværs og løse kerneopgaven bedre og smartere. Senere bestod det i at få skabt en forståelse af CURA som en ressource, man kunne have tillid til-"en god ven"-og endelig blev forventningerne, efter CURA var taget i brug, også forsøgt formet. Her handlede det mindre om platformens muligheder og mere om, 
at der ville være behov for tålmodighed, og en besindelse i forhold til at fælde hurtig dom over CURA.

\section{F. Diskussion}

Igennem et casestudie af et kommunalt digitalt transformationsinitiativ har vi udfoldet tre forandringsledelsespraksisser: tilpasnings-, tilslutnings- og forventningsledelse. Som illustreret i Figur 2, anser vi de tre ledelsespraksisser som supplerende, og kendetegnet ved, at de ikke anvendes sekventielt på forskellige tidspunkter, men bliver løbende mobiliseret igennem transformationsprocessen. I det følgende fremhæver og diskuterer vi centrale bidrag og læringspunkter, der kan uddrages fra studiet.

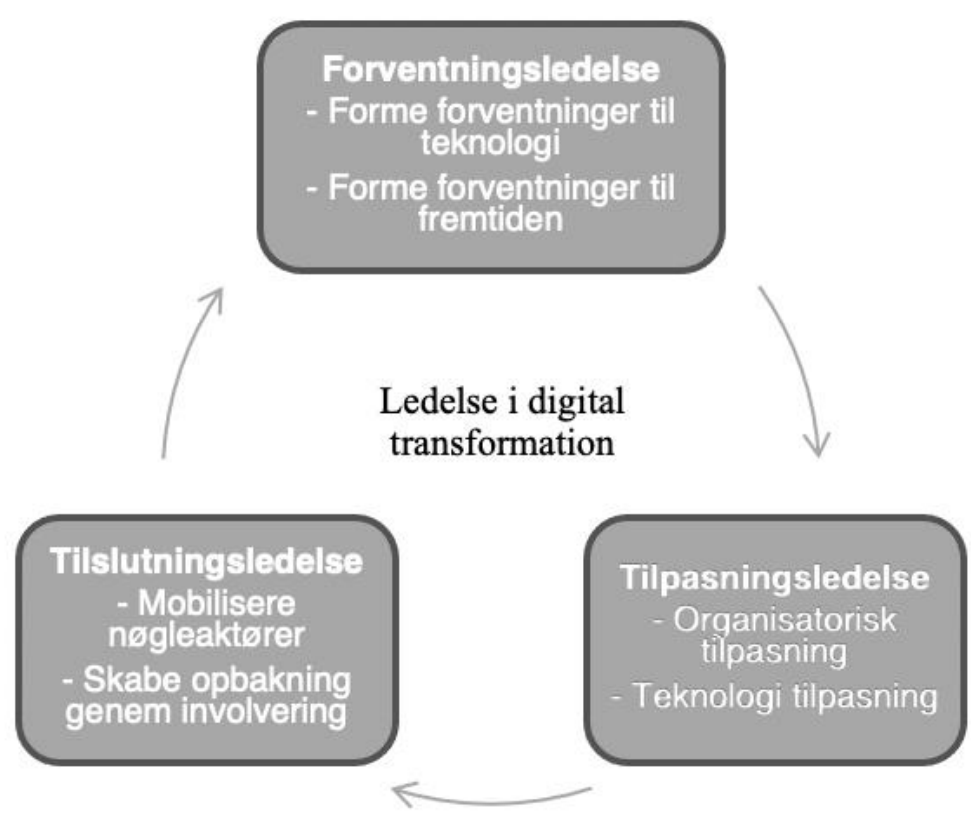

Figur 2: Tre praksisser i ledelse af digital transformation

For det første bidrager studiet med nye indsigter i, hvordan ledelse af digital transformation i den offentlige sektor kan forstås konstitueret gennem tre praksisser. De tre praksissier skal ikke forstås som sekventielt adskilte og faseopdelte, men snarere som sammenvævede, og som nogen der producerede retning til processen, hvilket involverede såvel projektledere, mellemledere som topledere (se også Crevani, 2018). Kombinationen af de tre forandringsledelsespraksisser er udtryk for, at ledelse af digital transformation kræver løbende omsorg og vedligeholdelse. Når det fx gælder forventningsledelse, viser vores studie, hvordan ledelsesopgaven ændrede sig undervejs. Hvor der i starten var fokus på at kommunikere og "sælge" mulighederne i den nye platform, blev et senere fokus, at medarbejderne måtte væbne sig med tålmodighed for at få platformen til at virke. Der er med andre ord tale om en løbende ledelse af medarbejdernes forventnings- og fremtidshorisont, som kræver "gode ører og øjne" fra ledelsens side. 
Mens den funktionalistiske forandringsledelseslitteratur betoner topledelsens rolle, forandringsfaser, og at motivere forandring (Kotter, 1995; Fernandez \& Rainey, 2006), viser vores case, at det ikke er tilstrækkeligt. Selvom topledelsen havde en afgørende rolle, ville et ensidigt fokus på en brændende platform være problematisk, da CURA ikke alene er et resultat af kommunens egne beslutninger, men også politisk medieret. Samtidig viser vores studie, at forandringsledelse er en iterativ proces, hvor konkrete forandringsledelsespraksisser må mobiliseres på vedholdende vis, og hvor en række aktører bliver væsentlige med-ledere i skabelsen af forandring. Denne betragtning er konsistent med den konstruktivistiske forandringsledelseslitteratur, som har fokuseret på mellemledere og forandring som en proces, hvor forventninger til fremtiden og tilskrivning af betydning er afgørende (Rouleau, 2005).

Vores studie adskiller sig også fra denne sidstnævnte litteratur ved at betone betydningen af digital teknologi. Studiet bidrager således til forståelsen af ledelse af digital transformation i den offentlige sektor, hvor vi fremhæver betydningen af det særlige ved at lede digital transformation. Med afsæt i litteraturen som peger på behovet for at belyse og forstå teknologiens særegne rolle og materialitet (Faulkner \& Runde, 2020; Orlikowski \& Iacano, 2001) fremhæver vi betydningen af at lede digital transformation igennem løbende formning af aktørernes teknologiforståelser. Som supplement til den generiske forandringsledelseslitteratur har vi fremhævet nødvendigheden $\mathrm{i}$ at inddrage et fokus på teknologiens fortolkningsmæssige fleksibilitet, hvilket vi argumenterer for, er grundlæggende for de tre identificerede ledelsespraksisser. For det første står det klart, at CURA ikke skal forstås som en fast deterministisk størrelse, der blot adopteres "as is". I stedet har vi vist, at CURA krævede løbende teknisk og organisatorisk tilpasning samt bred organisatorisk mobilisering. Den øgede organisatoriske opbakning samt det løbende arbejde med at tilpasse teknologien samt signalere væsentligheden i dette arbejde, tydeliggør hvordan fortolkningen af teknologien udviklede og ændrede sig over tid. Desuden arbejdede forvaltningsledelsen aktivt med at gøre opmærksom på den fortolkningsmæssige fleksibilitet i aktiviteterne, der berørte tilslutning og tilpasning, hvor medarbejdere blev opfordret til at bidrage til at forme CURA. Dog hører det med, at selvom medarbejderne, ofte i samarbejde med systemleverandøren, blev inkluderet i formningen af CURA, har platformen-og det indlejrede FSIII dokumentationssystem-nogle materielle dispositioner indskrevet i sit design, som begrænser, hvad der kan ændres. Derfor må arbejdsgange også tilpasse sig CURA.

Casen er samtidig en påmindelse om, at selvom forandringsledelsen er omfattende, er det ikke garanti for uproblematisk implementering og deraf følgende værdiskabelse. De tre identificerede forandringsledelsespraksisser-tilpasnings-, tilslutnings- og forventningsledelse- kunne samlet set synes at skabe et godt fundament for at opnå værdiskabelse, men de havde også utilsigtede konsekvenser. Ud over den åbenlyse økonomiske udgift forbundet med den omfattede 
forandringsledelsesindsats opbyggede forvaltningsledelsen meget høje forventninger til CURA. Så høje forventninger, at der i månederne efter ibrugtagningen begyndte at opstå tvivl om, hvorvidt CURA nogensinde kunne leve op til forventningerne. Det er ikke unormalt for digital transformation, at ledelsen "sælger forandringen" ud over det rimelige, for at sikre medarbejderopbakning og motivationen for projektet (Ashurst et al., 2008). Derfor er det vigtigt at opveje ønsket om at skabe tilslutning og høj motivation for digital transformation i forhold til risikoen for at skabe urealistiske forventninger.

\section{G. Konkluderende bemærkninger}

Ledelse af digital transformation i den offentlige sektor er i stigende grad på dagsordenen, men alligevel får mange digitaliseringstiltag ikke tilstrækkelig opmærksomhed. Selvom denne artikel har en række begrænsninger i form af sit single case design håber vi, at ledere og beslutningstagere i og omkring den offentlige sektor finder inspiration i begreberne tilpasnings- tilslutnings- og forventningsledelse i deres bestræbelser på at digitalisere den offentlige sektor, hvor det giver mening.

\section{Noter}

${ }^{1}$ Denne artikel indgår som et delelement af et større følgeforskningsprojekt, hvor forskere fra Aalborg Universitet følger implementeringen af CURA i Aalborg Kommune. Vi skal rette en tak til Rune Clausen for at gennemføre en række af de indledede interviews og studentermedhjælperne Camilla K. Caspersen og Matilde B.M. Andersen for at hjælpe med transskribering og kodning af det empiriske materiale.

${ }^{11}$ Det kan diskuteres hvorvidt de kritisk reaktionerne skyldes CURA eller om det snarere knytter sig til FSIII, der som nævnt, er indlejret i CURA platformen. Det er dog ikke et spørgsmål vi vil forfølge i denne artikel.

\section{Referencer}

Anthopoulos, L., Reddick, C.G., Giannakidou, I., Mavridis, N.(2016). Why eGovernment projects fail? An analysis of the healthcare. gov website. Government Information Quarterly 33(1), 161-17 https://doi.org/10.1016/j.giq.2015.07.003

Askedal, K., Flak, L. S., and Aanestad, M., (2019). Five Challenges for Benefits Management in Complex Digitalisation Efforts - and a Research Agenda to Address Current Shortcomings. The Electronic Journal of e-Government, 17 (2): 64-78. 
Ashurst, C., Doherty, N. F., \& Peppard, J. (2008). Improving the impact of IT development projects: the benefits realization capability model. European Journal of Information Systems, 17(4), 352-370. https://doi.org/10.1057/ejis.2008.33

Beer, M. \& Nohria, N. (2000). Cracking the code of change. Harvard Business Review 78, (3): 133-141.

Braun, V \& Clarke, C. (2013): Teaching thematic analysis: Overcoming challenges and developing strategies for effective learning. The psychologist. 26 (2)

Cameron, K. S., \& Quinn, R. E. (2011). Diagnosing and changing organizational culture: Based on the competing values framework. John Wiley \& Sons.

Crevani, L. (2018). Is there leadership in a fluid world? Exploring the ongoing production of direction in organizing. Leadership, 14 (1), 83-109. https://doi.org/10.1177/1742715015616667

Det Digitale Råd (2012). Digital ledelse. Debatoplæg om behovet for et paradigmeskifte i den offentlige sektor. København.

Dunleavy, P., Margetts, H., Bastow, S., \& Tinkler, J. (2006). New public management is dead: Long live digital-era governance. Journal of Public Administration Research and Theory, 16 (3), 467-494. https://doi.org/10.1093/acprof:oso/9780199296194.003.0009

Dwivedi, Yogesh K., David Wastell, Sven Laumer, Helle Zinner Henriksen, Michael D. Myers, Deborah Bunker, Elbanna Amany, M. N. Ravishankar, and Shirish C. Srivastava (2015). Research on Information Systems Failures and Successes: Status Update and Future Directions. Information Systems Frontiers 17 (1):143 - 57. https://doi.org/10.1007/s10796-014-9500-y

Ejersbo, N., \& Greve, C. (2016): 'Digital era governance reform and accountability: The case of Denmark' in T. Christensen \& P. Lægreid (eds.): The Routledge Handbook to Accountability and Welfare State Reforms in Europe, London, Routledge: 267-279. https://doi.org/10.4324/9781315612713

Elmholdt, C., Keller, H. D., \& Tanggaard. L. (2019). Ledelsespsykologi. 2. udgave. Samfundslitteratur. Elmholdt, K. T., Clausen, R. T. J., \& Madsen, M. T. (2018). Seductive Atmospheres: Using Tools to Effectuate Spaces for Leadership Development. Journal of Change Management, 18(4), 257-280. https://doi.org/10.1080/14697017.2018.1453856

EU (2018). eGovernment Benchmark 2018. Securing eGovernment for all. file://id.aau.dk/Users/agger/Downloads/eGovernmentBenchmark2018Insightreportpdf.pdf

Faulkner, P., \& Runde, J. (2019). Theorizing the digital object. MIS Quarterly, 43 (4): 1279-1302. 
Fernandez, S. \& Rainey, H.G. (2006). Managing successful organizational change in the public sector. Public Administration Review, 66 (2): 168-176. https://doi.org/10.1111/j.1540-6210.2006.00570.x

Gould, R. (2006). Public sector information system project failures: Lessons from a New Zealand hospital organization. Government Information Quarterly, 24 (1): 102-114 https://doi.org/10.1016/j.giq.2006.02.010

Goldfinch, S. (2007). Goldfinch Pessimism, computer failure, and information systems development in the public sector. Public Administration Review, 67(5), 917-929. https://doi.org/10.1111/j.1540$\underline{6210.2007 .00778 . x}$

Ford, J., Ford, L. \& D'amelio, A. (2008): Resistance to change: the rest of the story. Academy of Management 33 (2): 362-377. https://doi.org/10.5465/amr.2008.31193235

Hanelt, A., Bohnsack, R., Marz,D. \& Marante, C. A. (2020). A systematic review of the literature on digital transformation: Insights and implications for strategy and organizational Change. Journal of Management Studies. https://doi.org/10.1111/joms.12639

Hansen, M. B., \& Nørup, I. (2017). Leading the implementation of ICT innovations. Public Administration Review, 77(6), 851-860. https://doi.org/10.1111/puar.12807

Huy, Q.N. (2001). Time, temporal capability, and planned change. Academy of Management Review, 26 (4): 601-623. https://doi.org/10.5465/amr.2001.5393897

Jacobsen, D. I. (2019). Organisationsandringer og forandringsledelse. 3. Udgave. Samfundslitteratur. Jonathan G.M. (2020). Digital transformation in the public sector: Identifying critical success factors. In: Themistocleous M., Papadaki M. (eds). Information Systems. EMCIS 2019. Lecture Notes in Business Information Processing, Vol. 381. Springer, Cham. https://doi.org/10.1007/978$\underline{3-030-44322-1 \_17}$

Kanter, R. M., Stein, B. A. and Jick, T. D. (1992) The Challenge of Organizational Change. New York: The Free Press.

KL (2018): Fællessprog III. https://cura.aalborg.dk/om-cura).

Kotter, J. P. (1995). Leading Change-Why Transformation Efforts Fail. Harvard Business Review 73 (2): $59-67$.

Mengel, I., Edelmann, N., \& Haug, N. (2019). Defining digital transformation: Results from expert interviews. Government Information Quarterly, 36 (4), 101385

https://doi.org/10.1016/j.giq.2019.06.002

Nielsen, J. A., \& Andersen, J. G. (2006). Hjemmehjoelp: mellem myter og virkelighed. Syddansk Universitetsforlag. 
Nielsen, J. A., \& Pedersen, K. (2014). IT Portfolio Decision-making in Local Governments: Rationality, Politics, Intuition and Coincidences. Government Information Quarterly 31 (3): 411-420 https://doi.org/10.1016/j.giq.2014.04.002

Nielsen, J. A., Mathiassen, L., \& Newell, S. (2014). Theorization and translation in information technology institutionalization: Evidence from Danish home care. MIS Quarterly, 38 (1), 165-186 https://doi.org/10.25300/misq/2014/38.1.08

Mogensen, F. (2019). Implementering af elektronisk omsorgsjournal i kommunal setting. Tidsskrift for omsorgsforskning, 5 (3), 21-35. https://doi.org/10.18261/issn.2387-5984-2019-03-03

Orlikowski, W. J. (2000). Using technology and constituting structures: A practice lens for studying technology in organizations. Organization Science, 11(4), 404-428.

https://doi.org/10.1287/orsc.11.4.404.14600

Orlikowski, W. J., \& Iacono, C. S. (2001). Research commentary: Desperately seeking the "IT" in IT research-A call to theorizing the IT artifact. Information Systems Research, 12 (2), 121-134. https://doi.org/10.1287/isre.12.2.121.9700

Pinch, T. J., \& Bijker, W. E. (1984). The social construction of facts and artefacts: Or how the sociology of science and the sociology of technology might benefit each other. Social studies of science, 14 (3), 399-441. https://doi.org/10.1177/030631284014003004

Rouleau, L. (2005). Micro-practices of strategic sensemaking and sensegiving: How middle managers interpret and sell change every day. Journal of Management Studies, 42 (7), 1413-1441. https://doi.org/10.1111/j.1467-6486.2005.00549.x

Røhl, U. B.U, \& Nielsen, J. A, (2019). Sundhedsplatformen i modvind. En analyse af aktørernes teknologiforståelser i danske medier. Samfundslederskab i Skandinavien, 34 (3): 178-206. https://doi.org/10.22439/sis.v34i3.5810

Sahay S and Robey D (1996). Organisational context, social interpretation, and the implementation and consequences of geographic information systems. Accounting, Management and Information Technology 6 (4), 255-282. https://doi.org/10.1016/s0959-8022(96)90016-8

Vial, G. (2019). Understanding Digital Transformation: A Review and a Research Agenda. Journal of Strategic Information Systems 28: 118-144. https://doi.org/10.1016/j.jsis.2019.01.003

Weick, K. E., \& Quinn, R. E. (1999). Organizational change and development. Annual review of psychology, 50(1), 361-386. https://doi.org/10.1146/annurev.psych.50.1.361 
Wessel, L., Baiyere, A., Ologeanu-Taddei, R., Cha, J., \& Jensen, T. (2020). Unpacking the difference between digital transformation and IT-enabled organizational transformation. Journal of the Association for Information System 